\section{Illuminating Engineering}

THE paper on the electric lighting of buildings read by A. B. Read and Dr. J. W. T. Walsh to the Institution of Electrical Engineers on November 3 illustrates the change that has come over the art of illumination during recent years. Originally the aim was to provide as much light as possible for the very limited consumption of energy available. Happily, owing to the great advances made in the means of light production, engineers are no longer trammelled by tradition and new and daring experiments are being made in illuminating engineering similar to those made possible in architecture and decoration, due to the use of new constructional methods and materials. The second part of the paper deals with the engineering and physiological principles which govern design and gives a brief description of the new materials now available to the 'artist in light'. Architects now provide electric 'points' on their plans not for 'a light of some sort' but for a fitting in character with the room. Lighting by electricity can be done in many ways. It can be used to enhance the restful atmosphere of a place of worship, dignify a great public building, serve as a decorative element in a small house, or bring sparkle and gaiety to a restaurant. The latest development in light production is the gaseous discharge tube. The use of various mixtures of the rare gases provides a wonderful range of hues in the light available. The efficiency of the lamp also has been greatly improved. It gives three or four times as much light as the ordinary tungsten filament gas-filled lamp. The authors conclude by discussing the effects of glare, contrast, shadows and colour. The paper proves that the task of the lighting engineer is a difficult one.

\section{Report of the Strangeways Research Laboratory}

The Trustees' Report for 1931 on the Strangeways Research Laboratory, Cambridge, records as the outstanding event of the year the extension of the laboratory, made possible by a bequest of $£ 5000$ from the late Sir Otto Beit, and refers to the additional connecting links between the laboratory and the biological departments of the University which afford opportunities for valuable collaboration, for example, in zoology, nutrition and radiology. A résumé of the work in progress shows that Dr. H. B. Fell and her colleagues are carrying out with skilful technique investigations of great interest on tissue culture. Reference is made to the better results in the study of osteogenesis due to improvements in technique. Of the other work recorded we note Dr. P. D. F. Murray's studies on the development in vitro of the primary red blood corpuscles of the chick. Portions of fowl embryos removed from the egg after periods of incubation ranging from 1 to 18 hours were cultivated in a fluid medium composed of serum and embryo extract. Red blood corpuscles developed in all the cultures made from the posterior half of the primitive streak at the stage immediately preceding the formation of the headprocess, but portions of the anterior half, although differentiating into central nervous system and somites, formed no blood. All the stages in erythro. genesis could be followed in the living material. The first sign was a thickening in the tissue; the cells of this thickening diminished considerably in size and displayed great mitotic activity. Eventually they lost their adhesiveness, formed loose groups in the tissue or fell into the culture medium as a cloud of free erythroblasts in the cytoplasm of which hæmoglobin began to develop.

\section{Industrial Models at Hull Museum}

THE crushing of linseed and rape seed obtained from the plants of northern Europe has long been a staple industry at Hull, which now claims to be the largest oil-mill centre in the world. In view of this, it is interesting to learn that the Museum contains a remarkable series of models of seed-crushing plant illustrating both old and new methods. The models were described in the Model Engineer and Practical Electrician in April last and the articles have now been published in pamphlet form as Hull Museum Publication No. 176. The models have been made by Mr. W. Marshall, who began his connexion with the industry as a blacksmith in 1869 , rose to be manager of some of the largest mills and became a manufacturer of oil-mill plant. The beginning of the oil-seed industry is lost in the mists of antiquity but in certain parts of the world to-day very primitive plant is used. From these primitive devices came the lever press, the wedge press and the screw press, and in more modern times the hydraulic and steam power presses. These are all illustrated by Mr. Marshall's models, which are described in the pamphlet.

\section{Publications of the University of Bombay}

IN order to encourage research among teachers and students, the authorities of the University of Bombay have decided to issue a periodical publication, which will contain communications from members of the university and others dealing with research in the subjects of the University curriculum. The Journal of the University of Bombay, as the publication is to be called, will appear six times in each year, two of the parts being devoted to history, economics and sociology, two to arts and law, and one each to the physical sciences and the biological sciences. In addition to the original articles, there will be reviews of books, abstracts of academic theses and notes on current topics. The first issue, which has recently appeared, covering history, economics and sociology, contains several communications dealing with points in the history of sixteenth century India, India's trade and commercial relations, Indian art and sociology, the bearing of certain traditions on the origin of Konkan Brahmins, and articles of a more general character on trade unions and the League of Nations. Especially noteworthy is a lecture delivered in Bombay by M. Elie Faure on the interpretation of Indian art, in which it is suggested that a meetingground for Europe and India might emerge from their common inheritance from Greece. There is also an obituary notice of the late Sir Patrick Geddes, which does full justice to his work for India.

No. 3295, VoL. 130] 